\title{
Kejahatan Kekerasan Terhadap Anak dalam Perspektif Kriminologis di Kota Kendari
}

\section{Violent Crimes Against Children in Criminological Perspectives in Kendari City}

\author{
Iksan', Handrawan'2, Guasman Tatawu3 ${ }^{3}$, Rustam Ukkas ${ }^{4}$ \\ 1. Universitas Halu Oleo, Indonesia. E-mail: iksanrompo99@gmail.com \\ 2. Universitas Halu Oleo, Indonesia. E-mail: handrawansaranani84@gmail.com \\ 3. Universitas Halu Oleo, Indonesia. E-mail: gtatawu@gmail.com \\ 4. Universitas Halu Oleo, Indonesia. E-mail: rustamukkas59@gmail.com
}

\begin{tabular}{l}
\hline ARTICLE INFO \\
\hline Keywords: \\
Violence against \\
children; \\
Criminologist; \\
Preventive; \\
Repressive \\
\end{tabular}

\section{INFO ARTIKEL}

Kata kunci:
Kekerasan terhadap
anak;
Kriminologis;
Preventif;
Represif

\begin{abstract}
Some criminological theories that describe the cause of crime and all the underlying factors, are very much in line with the results of research that has been done. The results of research on violence against children are largely motivated by environmental conditions and the decline in the power of human control in relationships as a result of advances in social networking technology that is growing rapidly. Kendari City in 2019 ranked 2nd (Second) in Southeast Sulawesi province as the city with the highest level of vulnerability to violence against women and children with 54 cases a year. The violence occurred in the family environment. If described in more detail 54 cases have a quantity of disputes and quarrels as much as 627 with indications of violence due to polygamy as many as 4 cases out of 54 cases. Efforts to tackle child violent crime in the city of Kendari are carried out through two approaches namely preventive and repressive measures.
\end{abstract}

\footnotetext{
ABSTRAK

Beberapa teori kriminologis yang menguraikan tentang sebab terjadinya kejahatan dan segala faktor yang melandasinya, sangat sejalan dengan hasil penelitian yang telah dilakukan. Hasil penelitian tentang kekerasan terhadap anak banyak dilatar belakangi karena kondisi lingkungan serta menurunnya daya kontrol manusia dalam pergaulan sebagai akibat kemajuan teknologi jejaring sosial yang semakin berkembang dengan pesat. Kota Kendari pada tahun 2019 menempati urutan ke-2 (Kedua) di provinsi Sulawesi Tenggara sebagai kota yang tingkat kerawanan atas kekerasan terhadap perempuan dan anak tertinggi dengan 54 kasus dalam setahun. Kekerasan tersebut terjadi dalam lingkungan keluarga (Violence Domestic). Jika di jabarkan lebih detail 54 kasus tersebut memiliki kuantitas perselisihan dan pertengkaran yang terus menerus (Constant Disputes and Quarrel) sebanyak 627 dengan indikasi faktor kekerasan karena poligami sebanyak 4 kasus dari 54 kasus. Upaya penanggulangan atas kejahatan kekerasan anak di kota Kendari dilakukan melalui dua pendekatan yakni upaya preventif dan upaya represif.
} 


\section{Pendahuluan}

Manusia pada dasarnya memiliki dua sifat, yakni manusia sebagai makhluk individu dan manusia sebagai makhluk sosial. Manusia sebagai makhluk individu berarti setiap manusia memiliki perbedaan sifat dan tingkah laku yang khas, yang berasal dari sifat keturunan dari orang tuanya dan juga sifat dari lingkungan dimana ia tinggal. Sedangkan manusia sebagai makhluk sosial berarti setiap manusia tidak dapat hidup tanpa bantuan orang lain. Sifat manusia sebagai makhluk sosial lainnya yakni secara naluriah, manusia memiliki kebutuhan untuk berkomunikasi atau berbicara dengan manusia lainnya. Hal ini merupakan sifat mendasar yang dimiliki oleh manusia. ${ }^{1}$

Dalam perkembangan hidup manusia anak selalu di tempatkan pada bagian terpenting dalam sebuah kehidupan keluarga dan masyarakat, sebab setiap anak lahir dan tercipta untuk meneruskan perjalanan hidup orang tua dan keluarganya, sehingga tak jarang orang tua atau keluarga dapat menghalalkan segala cara untuk kepentingan sang anak. Pada prinsipnya orang tua selalu berupaya memberikan dan mengajarkan kebaikan serta kebijakan kepada anaknya baik secara psikologis, mental, dan jasmani secara maksimal kepada anaknya. Dalam memberikan pelayanan dan kebajikan kepada anaknya orang tua selalu memberikan pengajaran melalui pendidikan formal di sekolah maupun pendidikan yang berbasis mental spiritual di mana dalam hal ini negara ikut terlibat dalam proses peningkatan kualitas hidup anak bangsa. ${ }^{2}$

Ketentuan Undang-Undang Dasar Negara Republik Indonesia Tahun 1945 (selanjutnya disebut UUD NRI 1945) beserta perubahannya, Pasal 28 B Ayat (2) menegaskan bahwa segala bentuk kekerasan pada umumnya maupun tindak kekerasan terhadap perempuan dan/atau anak adalah suatu bentuk pelanggaran hak asasi manusia dan merupakan suatu bentuk kejahatan terhadap martabat kemanusiaan serta perlakuan diskriminasi.

Dasar tanggung jawab negara dalam perlindungan, pemajuan, penegakan, dan pemenuhan hak asasi dapat ditemukan dalam rumusan Pasal 28I ayat (4) dan (5) UUD NRI 1945 yang berbunyi:

(4) Perlindungan, pemajuan, penegakan, dan pemenuhan hak asasi manusia adalah tanggung jawab negara, terutama pemerintah.

(5) Untuk penegakan dan melindungi hak asasi manusia sesuai dengan prinsip negara hukum yang demokratis, maka pelaksanaan hak asasi manusia dijamin, diatur, dan dituangkan dalam peraturan perundang-undangan.

Rumusan Pasal 28 B Ayat (2) dan Pasal 28I ayat (4) dan (5) UUD NRI 1945 tersebut menegaskan Indonesia menganut prinsip bahwa negara dan pemerintah dalam hal ini pemerintah daerah memiliki tanggung jawab dalam mencegah dan menangani kasus kekerasan terhadap perempuan dan anak. Kekerasan terhadap perempuan dan anak bukan hanya merupakan perbuatan hukum yang berdimensi kriminal, tetapi juga

1 Asteria Putri Budylianti, “Aktivitas Komunitas Khonghucu di Kelenteng Hwie Ing Kiong Kota Madiun” (Universitas Islam Negeri Sunan Ampel Surabaya, 2016), 1.

2 Ayu Utami, Kejahatan Terhadap Kekerasan Anak (Bandung: Paramita, 2002), 12. 
merupakan penyimpangan perilaku sosial yang perlu segera di atasi oleh pemerintah daerah.

Seiring dengan perkembangan modernisasi saat ini telah meletakkan anak selalu dalam skala prioritas, tetapi tak jarang dijumpai anak selalu dijadikan sebagai alat untuk mencapai sesuatu, di mana anak dieksploitasi secara tidak wajar oleh keluarga dan lingkungannya. Eksploitasi dan kekerasan fisik banyak terjadi pada keluarga yang tingkat ekonominya berada di bawah garis kemiskinan, anak dipaksa untuk melakukan suatu pekerjaan yang melebihi batas kewajaran seperti menjadikan anak sebagai pengamen jalanan maupun anak sering dijadikan sebagai obyek pelampiasan bagi keluarga yang disharmonis.

Di Indonesia berdasarkan Komisi Perlindungan Anak Indonesia (KPAI) mencatat masih banyak terjadi tindak kekerasan pada anak Indonesia hingga saat ini. Setidaknya, selama 2019, mereka telah menerima 1.192 laporan terkait kekerasan yang dialami anak di bawah umur. ${ }^{3}$

Catatan Komisi Perlindungan Anak tersebut di atas menunjukkan bahwa angka kekerasan terhadap anak cukup memprihatinkan dan peristiwa tersebut tidak tertutup kemungkinan juga dapat terjadi di wilayah hukum Sulawesi Tenggara khususnya di Kota Kendari.

Kota Kendari dalam proses perkembangannya di berbagai aspek masih dihadapkan pada berbagai persoalan baik persoalan pendidikan, kemiskinan maupun keamanan dan ketertiban. Hal tersebut telah mendorong kehidupan yang tidak wajar dalam pergaulan masyarakat sehingga melahirkan peningkatan kejahatan di Kota Kendari terutama mengenai kekerasan terhadap anak.

Pra penelitian ditemukan fakta bahwa Sulawesi Tenggara anak kekerasan pada tahun 2019 sebanyak 286. ${ }^{4}$ Kota Kendari pada tahun 2019 menempati urutan ke-2 (Kedua) di provinsi Sulawesi Tenggara sebagai kota yang tingkat kerawanan atas kekerasan terhadap perempuan dan anak tertinggi dengan 54 kasus dalam setahun. Kekerasan tersebut terjadi dalam lingkungan keluarga (Violence Domestic). Jika di jabarkan lebih detail 54 kasus tersebut memiliki kuantitas perselisihan dan pertengkaran yang terus menerus (Constant Disputes and Quarrel) sebanyak 627 dengan indikasi faktor kekerasan karena poligami sebanyak 4 kasus dari 54 kasus. $^{5}$

Kebenaran korespondensi atas kekerasan terhadap perempuan dan anak di Sulawesi Tenggara mencapai atas, membuktikan bahwa perlu ada langkah konkret yang harus

3 Marisa Safitri, “Selama 2019, KPAI Terima Seribu Kasus Kekerasan Anak," IDN Times, diakses Februari 10, 2020, https://jabar.idntimes.com/news/indonesia/marisa-safitri-2/kpai-kekerasan-anak-palingbanyak-terjadi-dalam-pengasuhan-regional-jabar/full.

4 Kementerian Agama RI, Dirjen Bimas Islam/Ministry of Religious Affairs, Directorate General of Islamic Community Guidance, dalam Badan Pusat Statistik Provinsi Sulawesi Tenggara, Provinsi Sulawesi Tenggara dalam Angka 2020, Penyediaan Data Untuk Perencanaan Pembangunan (Kendari: Badan Pusat Statistik Provinsi Sulawesi Tenggara, 2020), 191.

5 Ibid. 
segera dilakukan (emergency crime). Secara konseptual salah satu bentuk upaya yang dapat dilakukan oleh pemerintah daerah kota Kendari adalah dengan membentuk Pusat Pelayanan Terpadu Perlindungan Perempuan dan Anak (P2TP2A) lembaga ini adalah lembaga yang dibentuk pemerintah daerah untuk memberikan layanan pada perempuan dan anak yang mengalami permasalahan. Di Kota Kendari, setiap tahun P2TP2A menerima laporan tindak kekerasan.

Gambaran tersebut di atas, merupakan kajian awal penulis dengan melihat dan menelaah secara obyektif terhadap peristiwa kekerasan terhadap anak yang terjadi saat ini di Indonesia maupun Kota Kendari. Berdasarkan fenomena tersebut penulis memilih judul "Kekerasan Terhadap Anak Dalam perspektif Kriminologi di Kota Kendari".

\section{Metode}

Tipe penelitian yang digunakan dalam penelitian ini adalah penelitian hukum normatifempiris yaitu dengan melihat, mengamati aturan-aturan yang berlaku di dalam masyarakat Kota Kendari berkaitan kejahatan kekerasan anak yang pernah terjadi. Populasi dalam penelitian ini adalah seluruh kasus kekerasan terhadap anak yang terjadi di Kota Kendari dan unsur-unsur yang terkait yaitu pelaku, korban dan pihak kepolisian Polresta Kendari. Sampel diambil berdasarkan populasi yang dianggap cukup representatif untuk mewakili keseluruhan populasi dengan membatasi waktu terjadinya, yaitu hanya terhadap kasus-kasus yang terjadi antara tahun 2016-2019. sedangkan unsurunsur yang terkait dalam kasus ini sekaligus dijadikan responden dengan rincian sebagai berikut: 3 orang korban, 3 orang pelaku dan 1 orang penyidik dari Polresta Kendari.

\section{Faktor Penyebab Terjadinya Kekerasan Terhadap Anak di Kota Kendari}

Secara umum ruang lingkup kriminologi meliputi faktor-faktor penyebab kejahatan, gejala-gejala kejahatan, latar belakang kejahatan serta reaksi lembaga-lembaga sosial masyarakat yang dapat mempengaruhi kecenderungan dan penyimpangan norma-norma hukum. Untuk dapat mencegah lahirnya tindakan tersebut maka perlu adanya sebuah tindakan yang mengarah pada kebijaksanaan sosial sebagai suatu tindakan reaktif yang terstruktur dan terarah di dalam kehidupan masyarakat. ${ }^{6}$

Kondisi sosial dalam lingkungan masyarakat dan perkembangan zaman yang begitu cepat dapat mengakibatkan adanya konflik-konflik eksternal maupun internal di dalam masyarakat serta dalam pergaulan hidup individu dalam masyarakat. Terjadinya perubahan dan perkembangan ilmu pengetahuan dan teknologi di dalam suatu lingkungan masyarakat yang tidak diimbangi dengan perkembangan, pembinaan sosial di dalam pergaulan masyarakat justru akan mengakibatkan hal-hal yang sifatnya negatif. Hal tersebut menyebabkan corak berpikir masyarakat kadang tidak realistis dalam mengungkap dan memahami etika dalam tatanan hidup bermasyarakat sehingga membawa masyarakat untuk melakukan suatu tindakan yang di anggap menyalahi

6 Romli Atmasasmita, Bunga Rampai Kriminologi (Jakarta: Rajawali Pers, 1984), 53. 
norma-norma yang berlaku di dalam lingkungan kehidupan mereka, seperti melakukan kejahatan dan kekerasan. ${ }^{7}$

Kekerasan pada umumnya ditujukan kepada kelompok yang dianggap lemah, anak merupakan salah satu kelompok yang rentan mendapatkan perilaku kekerasan tersebut. ${ }^{8}$ Kekerasan terhadap anak adalah semua bentuk/tindakan perlakuan menyakitkan secara fisik ataupun emosional, penyalahgunaan seksual, trafficking, penelantaran, eksploitasi komersial termasuk eksploitasi seksual komersial anak yang mengakibatkan cedera/kerugian nyata ataupun potensial terhadap kesehatan anak, kelangsungan hidup anak, tumbuh kembang anak atau martabat anak, yang dilakukan dalam konteks hubungan tanggung jawab, kepercayaan atau kekuasaan. ${ }^{9}$ Ninik Widiyanti dan Yulius Waskita, menyatakan bahwa terjadinya suatu kejahatan sangatlah berhubungan dengan kemiskinan, pendidikan, pengangguran, dan faktor-faktor sosial ekonomi lainnya utamanya pada negara berkembang, di mana pelanggaran norma dilatar belakangi oleh hal-hal tersebut. ${ }^{10}$

Ada berbagai macam faktor penyebab terjadinya kekerasan terhadap anak yaitu antara lain: ${ }^{11}$

\section{Faktor Internal}

a. Berasal dari dalam diri anak

Terjadinya kekerasan terhadap anak dapat disebabkan oleh kondisi dan tingkah laku anak. Kondisi anak tersebut misalnya: Anak menderita gangguan perkembangan, ketergantungan anak pada lingkungannya, anak mengalami cacat tubuh, retardasi mental, gangguan tingkah laku, anak yang memiliki perilaku menyimpang dan tipe kepribadian dari anak itu sendiri.

b. Keluarga/orang tua

Faktor orang tua atau keluarga juga memegang peranan penting terhadap terjadinya kekerasan pada anak. Beberapa contoh seperti orang tua yang memiliki pola asuh membesarkan anaknya dengan kekerasan atau penganiayaan, keluarga yang sering bertengkar mempunyai tingkat tindakan kekerasan terhadap anak yang lebih tinggi dibandingkan dengan keluarga yang tanpa masalah, orang tua tunggal lebih memungkinkan melakukan tindakan kekerasan terhadap anak karena faktor stres yang dialami orang tua tersebut, orang tua atau keluarga belum memiliki kematangan psikologis sehingga melakukan kekerasan terhadap anak, riwayat orang tua dengan kekerasan pada masa kecil juga memungkinkan melakukan kekerasan pada anaknya.

7 Topo Santoso dan Eva Achjani Zulfa, Kriminologi (Jakarta: Raja Grafindo Persada, 2001), 8.

8 Widiyanti Ninik dan Yulius Waskita, Kejahatan Dalam Masyarakat dan Penegakannya (Jakarta: Bina Aksara, 1987), 39.

9 Ibid.

10 Ibid., 62.

11 Syani Abdul, Kejahatan dan Penyimpangan Suatu Perspektif Kriminologi (Jakarta: Bina Aksara, 1987), 63. 
2. Faktor Eksternal

a. Lingkungan luar

Kondisi lingkungan juga dapat menjadi penyebab terjadinya kekerasan terhadap anak, di antaranya seperti kondisi lingkungan yang buruk, terdapat sejarah penelantaran anak, dan tingkat kriminalitas yang tinggi dalam lingkungannya.

b. Media massa

Media massa merupakan salah satu alat informasi. Media massa telah menjadi bagian dari kehidupan manusia sehari-hari dan media ini tentu mempengaruhi penerimaan konsep, sikap, nilai dan pokok moral. Seperti halnya dalam media cetak menyediakan berita-berita tentang kejahatan, kekerasan, pembunuhan. Kemudian media elektronik seperti radio, televisi, video, kaset dan film sangat mempengaruhi perkembangan kejahatan yang menampilkan adegan kekerasan, menayangkan film action dengan perkelahian, acara berita kriminal, penganiayaan, kekerasan bahkan pembunuhan dalam lingkup keluarga. Pada hakikatnya media massa memiliki fungsi yang positif, namun jika di salah gunakan maka dapat menjadi negatif.

3. Budaya

Budaya yang masih menganut praktik-praktik dengan pemikiran bahwa status anak yang dipandang rendah sehingga ketika anak tidak dapat memenuhi harapan orang tua maka anak harus dihukum. Bagi anak laki-laki misalnya, adanya nilai dalam masyarakat bahwa anak laki-laki tidak boleh cengeng atau anak laki-laki harus tahan uji. Pemahaman itu mempengaruhi dan membuat orang tua ketika memukul, menendang, atau menindas anak adalah suatu hal yang wajar untuk menjadikan anak sebagai pribadi yang kuat dan tidak boleh lemah.

Teori asosiasi diferensial yang dikemukakan oleh Sutherland terdiri atas 9 (Sembilan) proposisi yaitu: (1) Tingkah laku jahat itu dipelajari Sutherland menyatakan bahwa tingkah laku itu diwarisi sehingga tidak mungkin ada orang jahat secara mekanis, (2) Tingkah laku jahat itu dipelajari dari orang-orang lain dalam suatu proses interaksi dan (3) Bagian yang terpenting dari tingkah laku jahat dipelajari, diperoleh dalam kelompok pergaulan yang akrab. ${ }^{12}$

Beberapa teori kriminologis di atas yang menguraikan tentang sebab-musabab terjadinya kejahatan dan segala faktor yang melandasinya, sangat sejalan dengan hasil penelitian yang telah dilakukan. Hasil penelitian tentang kekerasan terhadap anak banyak dilatar belakangi karena kondisi lingkungan serta menurunnya daya kontrol manusia dalam pergaulan sebagai akibat kemajuan teknologi jejaring sosial yang semakin berkembang dengan pesat.

Menurut Aiptu Herawati Selaku Kanit PPA Polres Kendari mengatakan bahwa ada beberapa faktor yang menyebabkan terjadinya kekerasan anak di kota Kendari yaitu (wawancara pada tanggal 14 September 2019 jam 10.00):

12 G.W. Bawengan, Masalah Kejahatan dan Sebab Akibat (Jakarta: Pradnya Paramita, 1979), 43. 
1. Faktor Perkembangan Media Sosial

2. Faktor adanya kesempatan dari si pelaku

3. Faktor Pergaulan Bebas

Untuk memperjelas dan mempertegas kasus kekerasan terhadap anak di Kota Kendari, berikut ini penulis akan menyajikan dalam bentuk tabel mengenai jumlah kasus kekerasan terhadap anak di Kota Kendari mulai tahun 2016-2019 sehingga dapat diperoleh gambaran secara nyata mengenai kasus tersebut.

Tabel 1. Perkara Tindak Pidana Kekerasan Terhadap Anak yang Terjadi di Wilayah Hukum Polres Kota Kendari Bulan Januari 2016-Bulan Oktober 2019.

\begin{tabular}{ccccc}
\hline No. & Tahun & Jumlah Laporan Polisi & Usia Pelaku & Ket \\
\hline 1 & 2016 & 11 Kasus & Dewasa & - \\
2. & 2017 & 11 Kasus & Dewasa & - \\
3. & 2018 & 6 Kasus & Anak & 1 Pelaku Anak \\
4. & 2019 & 6 Kasus & Anak & 2 Pelaku Anak \\
\hline
\end{tabular}

Sumber: Polres Kota Kendari Tahun 2019 (Hasil Olahan Data).

Dari tabel di atas dapat di jelaskan bahwa pada tahun 2016 dan 2017 terdapat 11 kasus kekerasan terhadap anak yang di lakukan oleh orang dewasa, sedangkan di tahun 2018 terdapat 6 kasus kekerasan terhadap anak. Dari 6 kasus kekerasan yang terjadi di tahun 2018 terdapat 1 orang yang pelakunya masih di bawah umur. Sedangkan di tahun 2019 juga terdapat 6 kasus kekerasan terhadap anak dan dari 6 kasus tersebut di tahun 2019, 2 di antaranya pelakunya adalah seorang anak.

Tabel 2. Data Status Kekerasan Terhadap Anak di Kota Kendari.

\begin{tabular}{ccccc}
\hline & & & \multicolumn{2}{c}{ Status Kasus } \\
\cline { 3 - 5 } No. & Tahun & Jumlah Kasus & Dilimpahkan & Tidak Dilimpahkan \\
\hline 1. & 2016 & 11 Kasus & $\sqrt{ }$ & - \\
2. & 2017 & 11 Kasus & $\sqrt{ }$ & - \\
3. & 2018 & 6 Kasus & $\sqrt{ }$ & - \\
4. & 2019 & 6 Kasus & $\sqrt{ }$ & - \\
\hline
\end{tabular}

Sumber: Polres Kota Kendari Tahun 2019 (Hasil Olahan Data).

Dari tabel di atas dapat di jelaskan bahwa kasus kekerasan terhadap anak yang terjadi di kota Kendari mulai tahun 2016 sampai tahun 2019 ke semuanya di limpahkan ke Pengadilan Negeri Kendari untuk disidangkan.

Hasil penelitian ini juga menujukan bahwa perkara kekerasan terhadap anak lebih banyak melibatkan pelajar pada tataran usia yang sama. Kekerasan anak yang terjadi meliputi kekerasan fisik, psikis dan seksual. Kekerasan fisik dapat berupa sentuhan kekerasan yang terkadang mengakibatkan luka hal ini terjadi baik karena perilaku pola bercanda yang berlebihan maupun karena faktor sakit hati. Kekerasan psikis yang melibatkan anak-anak 
dapat berupa kekerasan verbal yang menimbulkan tekanan dan ketakutan. Kekerasan seksual terjadi melibatkan antar pelajar dengan pelajar yang dilakukan karena adanya hubungan pacaran yang sudah ada sebelumnya.

Penelitian ini juga menunjukkan bahwa upaya penyelesaian kasus kekerasan anak yang melibatkan dengan anak dapat dimungkinkan untuk diselesaikan melalui pendekatan Alternative Dispute of Resoluition (ADR) atau penyelesaian perkara secara non litigasi dengan mengacu kepada Perkab Kopolri Nomor 17 tahun 2008 dengan ketentuan perkara tersebut dapat dimungkinkan diselesaikan melalui mekanisme ADR berdasarkan penilaian subyektif dari penyidik atas usulan pihak-pihak yang berperkara. Selain itu mekanisme ADR hanya dapat dilakukan apabila upaya tersebut dilakukan sebelum terbitnya surat perintah dimulainya penyidikan (SPDP).

Hasil penelitian ini juga di memperoleh gambaran bahwa tidak ada data yang terdokumentasikan terkait kasus-kasus yang diselesaikan melalui mekanisme ADR atau non litigasi sebab perkara tersebut belum diterbitkan SPDP sehingga belum dapat dilakukan pencatatan sebagai perbuatan kriminal tetapi perkara yang di dokumentasi hanya perkara yang dimungkinkan untuk dilimpahkan dengan ketentuan menurut Undang-undang perlindungan anak perlu di tindak lanjuti ditingkat penuntutan. Selain itu, tidak dilakukannya pencatatan data yang diselesaikan melalui ADR karena UndangUndang tentang Sistem Peradilan Anak memberikan ruang untuk mediasi penal atau diversi.

\section{Upaya yang Dilakukan oleh Aparat Terkait dalam Mencegah dan Menanggulangi Terjadinya Kekerasan Terhadap Anak di Kota Kendari}

Dari sudut kriminologi setiap tindakan atau perbuatan tertentu yang tidak disetujui oleh masyarakat diartikan sebagai kejahatan. Hal ini dapat dicermati bahwa setiap kejahatan tidak harus dirumuskan terlebih dahulu dalam suatu peraturan hukum pidana. Apabila perbuatan yang dilakukan itu telah merugikan, membahayakan, dan tidak disukai masyarakat atau bahkan menjengkelkan, maka perbuatan tersebut dikatakan sebagai kejahatan. Dengan demikian perbuatan yang anti sosial pun juga termasuk sebagai suatu kejahatan. ${ }^{13}$

Kejahatan tidak pernah diberantas secara tuntas, kejahatan hanya dapat dicegah, dikurangi atau ditanggulangi. Berbagai macam upaya telah dilakukan dalam bidang pencegahan kejahatan oleh instansi-instansi kepolisian, kejaksaan, pengadilan dan lembaga pemasyarakatan. Dalam hal ini Mardjono Reksodiputro menegaskan bahwa pencegahan kejahatan mencakup segala usaha yang dilakukan oleh pemerintah (negara) dan masyarakat terhadap kemungkinan terjadinya kejahatan (dan mereka yang

13 Made Darma Weda, Kriminologi (Jakarta: Raja Grafindo Persada, 1996), 12. 
mempunyai potensi untuk melakukan kejahatan) maupun setelah terjadinya kejahatan (penyelidikan, pemeriksaan, peradilan, dan pembinaan si pelanggar hukum). ${ }^{14}$

Setelah penulis menguraikan beberapa faktor yang menyebabkan terjadinya kekerasan terhadap anak di Kota Kendari berdasarkan fakta yang diperoleh di lapangan dan juga dari hasil wawancara maupun dokumentasi, maka dapat dijadikan patokan untuk mencari upaya pencegahan dan penanggulangan sedini mungkin terhadap terjadinya kekerasan terhadap anak di kota Kendari. dari hasil wawancara yang di lakukan oleh penulis kepada Aiptu Herawati selaku Kanit PPA di Polres Kota Kendari ada beberapa upaya yang dilakukan oleh aparat terkait dalam mengupayakan untuk mencari alternatif yang dapat mencegah, mengurangi, menanggulangi dan meniadakan terjadinya kekerasan terhadap anak khususnya di wilayah hukum Kota Kendari. upaya-upaya tersebut antara lain (wawancara pada tanggal 14 September 2019 jam 10.00):

\subsection{Upaya preventif}

Adapun Upaya preventif ini dimaksudkan agar setiap personil anggota kepolisian dapat menjalankan rangkaian kegiatan pengamanan dengan menekankan peran dan fungsi kepolisian sebagai sentral pelayanan masyarakat. Upaya ini dilakukan untuk mencegah terjadinya kekerasan terhadap anak baik yang di lakukan oleh orang tuanya sendiri maupun yang di lakukan oleh orang lain. adapun upaya-upaya preventif yang dilakukan oleh Polres Kota Kendari Menurut Aiptu Herawati adalah sebagai berikut:

a. Melakukan penyuluhan hukum kepada masyarakat tentang bahaya dan ancaman hukuman yang dapat ditimbulkan dari kejahatan kekerasan terhadap anak.

b. Melakukan kegiatan penyuluhan hukum secara terpadu tentang Undang-Undang kekerasan dalam rumah tangga (KDRT) yang di dalamnya juga telah termasuk dengan kekerasan anak, serta Undang-Undang tentang Perlindungan Anak.

c. Memberikan penjelasan kepada masyarakat mengenai tindakan-tindakan apa saja yang harus dilakukan oleh masyarakat di dalam suatu lingkungan masyarakatnya apabila telah terjadi kekerasan terhadap anak.

d. Memberikan pemahaman kepada masyarakat mengenai langkah-langkah apa saja yang harus dilakukan pada saat menyaksikan dan melihat ada seseorang yang melakukan kekerasan terhadap anak.

e. Menyampaikan terhadap para orang tua melalui kegiatan seminar maupun workshop tentang tata cara mendidik anak yang baik dan benar.

f. Pihak aparat penegak hukum bekerja sama dengan tokoh agama, tokoh adat, dan tokoh masyarakat untuk melakukan pencegahan dini terhadap kejahatan kekerasan terhadap anak dengan menerapkan pembelajaran yang berbasis mental spiritual.

Upaya-upaya preventif tersebut di atas menurut Aiptu Herawati selaku Kanit PPA di Polres Kota Kendari merupakan kegiatan rutin yang sering dilakukan oleh pihak aparat

14 Mardjono Reksodiputro, Kriminologi dan Sistem Peradilan Pidana (Jakarta: Pusat Pelayanan Keadilan dan Pengabdian Hukum (d/h Lembaga Kriminologi) Universitas Indonesia, 1994), 12. 
penegak hukum khususnya Polres kota Kendari dalam rangka mencegah kejahatan kekerasan terhadap anak. Dari proses wawancara oleh penulis kepada Aiptu Herawati Selaku Kanit PPA Polres Kota Kendari, diakui peningkatan kekerasan terhadap anak saat ini oleh Pihak Kepolisian belum mampu menekan angka kejahatan kekerasan terhadap anak yang diakibatkan adanya pengaruh media cetak dan elektronik yang perkembangannya begitu cepat, sehingga tidak diimbangi dengan pembinaan sosial untuk itu seluruh elemen baik itu pemerintah, tokoh agama, tokoh adat, tokoh masyarakat dan orang tua harus mampu berpartisipasi aktif dalam rangka menekan angka laju kekerasan terhadap anak, sehingga tidak hanya semata-mata memberikan tanggung jawab kepada Pihak Kepolisian secara institusi, personal melainkan hal tersebut adalah merupakan tanggung jawab secara keseluruhan baik oleh kepolisian maupun masyarakat dan orang tua (wawancara tanggal 16 September 2019, jam 09.00).

\subsection{Upaya represif}

Selain upaya-upaya preventif yang di lakukan oleh aparat penegak hukum dalam hal ini pihak kepolisian Polres Kota Kendari, ada pula upaya-upaya yang bersifat represif yang di lakukan untuk menekan terjadinya kekerasan terhadap anak di Kota Kendari dengan instrumen memberikan efek jera kepada para pelaku.

Menurut Aiptu Herawati Upaya represif merupakan upaya penindakan dan penegakan hukum terhadap ancaman faktual dengan sanksi yang tegas dan konsisten dapat membuat jera para pelaku kekerasan terhadap anak.

Adapun upaya represif yang di lakukan oleh aparat penegak hukum Polres Kota Kendari Menurut Aiptu Herawati (Wawancara Tanggal 16 September 2019, jam 09.00)yaitu antara lain sebagai berikut:

a. Menerapkan sanksi yang tegas kepada para pelaku kejahatan kekerasan terhadap anak.

b. Menerapkan peraturan perundang-undangan yang tegas terkait dengan kekerasan anak di kota Kendari.

c. Upaya penyelidikan cepat dan tanggap terhadap adanya laporan dari masyarakat, dan keluarga mengenai perihal kekerasan terhadap anak di kota Kendari.

Berdasarkan penjelasan tersebut di atas, penulis melihat upaya-upaya yang dilakukan oleh pihak kepolisian Polresta Kendari belum memberikan hasil yang maksimal. Hal ini terlihat dari masih adanya kasus kekerasan terhadap anak yang terjadi di kota Kendari dari tahun 2016-2019. Namun pihak Polresta Kendari masih terus berupaya untuk menekan terjadinya kekerasan terhadap anak di kota Kendari.

Hal-hal tersebut di atas merupakan rangkaian tindakan represif yang dilakukan oleh aparat penegak hukum khususnya oleh pihak aparat penegak hukum kota Kendari dalam rangka menekan angka kekerasan terhadap anak dengan asumsi bahwa kepada para pelaku dapat merasakan efek jera atas rangkaian tindakan yang dilakukannya dan menyadari bahwa perbuatan yang dilakukan tersebut sangat bertentangan dengan 
tatanan hukum formal di Indonesia serta tatanan kaidah yang tumbuh dalam pergaulan hidup masyarakat serta di harapkan dengan adanya upaya represif tersebut dapat menekan angka kekerasan terhadap anak di kota Kendari sehingga dapat tercipta suasana aman dan tertib hukum dalam pergaulan masyarakat.

\section{Kesimpulan}

Faktor-faktor yang menjadi penyebab terjadinya kekerasan terhadap anak di Kota Kendari yaitu antara lain faktor internal yang terdiri dari faktor yang berasal dari dalam diri seorang anak, dan faktor keluarga. Sedangkan faktor eksternal yang terdiri dari faktor lingkungan luar, faktor media massa, faktor ilmu pengetahuan dan teknologi (IPTEK), dan faktor budaya. Upaya-Upaya yang dilakukan oleh aparat kepolisian Polres Kota Kendari dalam mencegah dan menanggulangi terjadinya kekerasan anak di Kota Kendari yaitu:1. Upaya Preventif yaitu upaya yang di lakukan oleh pihak kepolisian dalam hal ini Polres Kota Kendari dalam mencegah, mengurangi, dan menghapuskan kejahatan. Dalam upaya ini yang di tekankan adalah berupaya semaksimal mungkin untuk menghilangkan kesempatan untuk dilakukannya kejahatan terhadap kekerasan anak, sedangkan 2. Upaya Represif adalah upaya yang di lakukan oleh aparat kepolisian Polres Kota Kendari setelah terjadinya suatu kejahatan, seperti menindak para pelakunya sesuai dengan perbuatan yang mereka lakukan, agar mereka sadar bahwa perbuatan yang mereka lakukan adalah perbuatan yang melanggar hukum dan merugikan masyarakat.

\section{Daftar Pustaka}

Abdul, Syani. Kejahatan dan Penyimpangan Suatu Perspektif Kriminologi. Jakarta: Bina Aksara, 1987.

Atmasasmita, Romli. Bunga Rampai Kriminologi. Jakarta: Rajawali Pers, 1984.

Badan Pusat Statistik Provinsi Sulawesi Tenggara. Provinsi Sulawesi Tenggara dalam Angka 2020, Penyediaan Data Untuk Perencanaan Pembangunan. Kendari: Badan Pusat Statistik Provinsi Sulawesi Tenggara, 2020.

Bawengan, G.W. Masalah Kejahatan dan Sebab Akibat. Jakarta: Pradnya Paramita, 1979.

Budylianti, Asteria Putri. “Aktivitas Komunitas Khonghucu di Kelenteng Hwie Ing Kiong Kota Madiun.” Universitas Islam Negeri Sunan Ampel Surabaya, 2016.

Ninik, Widiyanti, dan Yulius Waskita. Kejahatan Dalam Masyarakat dan Penegakannya. Jakarta: Bina Aksara, 1987.

Reksodiputro, Mardjono. Kriminologi dan Sistem Peradilan Pidana. Jakarta: Pusat Pelayanan Keadilan dan Pengabdian Hukum (d/h Lembaga Kriminologi) Universitas Indonesia, 1994.

Safitri, Marisa. "Selama 2019, KPAI Terima Seribu Kasus Kekerasan Anak." IDN Times. Diakses Februari 10, 2020. https://jabar.idntimes.com/news/indonesia/marisasafitri-2/kpai-kekerasan-anak-paling-banyak-terjadi-dalam-pengasuhan-regionaljabar/full. 
P-ISSN: 2548-1762 | E-ISSN: 2548-1754

Santoso, Topo, dan Eva Achjani Zulfa. Kriminologi. Jakarta: Raja Grafindo Persada, 2001. Utami, Ayu. Kejahatan Terhadap Kekerasan Anak. Bandung: Paramita, 2002.

Weda, Made Darma. Kriminologi. Jakarta: Raja Grafindo Persada, 1996. 